\title{
Article \\ Comparative Analysis of Chloramphenicol-Resistant Enterococcus faecalis Isolated from Dairy Companies in Korea
}

\author{
Sung Hyun Bae ${ }^{1}\left(\right.$, Sunghyun Yoon ${ }^{1,2}{ }^{\oplus}$, Koeun Kim ${ }^{1} \oplus$, Yeong Bin Kim ${ }^{1,3}{ }^{\mathbb{D}}$ and Young Ju Lee ${ }^{1, *}$ \\ 1 College of Veterinary Medicine and Zoonoses Research Institute, Kyungpook National University, \\ Daegu 41566, Korea; gtroyro@gmail.com (S.H.B.); goguma0707@gmail.com (S.Y.); \\ kke02062@gmail.com (K.K.); kimybins@gmail.com (Y.B.K.) \\ 2 Division of Microbiology, National Center for Toxicological Research, U.S. Food and Drug Administration, \\ Jefferson, AR 72079, USA \\ 3 Division of Bacterial Disease, Bureau of Infection Disease Diagnosis Control, Korea Disease Control and \\ Prevention Agency, Osong 28159, Korea \\ * Correspondence: youngju@knu.ac.kr; Tel.: +82-53-950-7793
}

Citation: Bae, S.H.; Yoon, S.; Kim, K.; Kim, Y.B.; Lee, Y.J. Comparative Analysis of Chloramphenicol-

Resistant Enterococcus faecalis Isolated from Dairy Companies in Korea. Vet. Sci. 2021, 8, 143. https://doi.org/ $10.3390 /$ vetsci8080143

Academic Editors: Chengming Wang, Ihab Habib and Patrick Butaye

Received: 27 May 2021

Accepted: 24 July 2021

Published: 27 July 2021

Publisher's Note: MDPI stays neutral with regard to jurisdictional claims in published maps and institutional affiliations.

Copyright: (c) 2021 by the authors. Licensee MDPI, Basel, Switzerland. This article is an open access article distributed under the terms and conditions of the Creative Commons Attribution (CC BY) license (https:// creativecommons.org/licenses/by/ $4.0 /)$.

\begin{abstract}
Although chloramphenicol is currently banned from use in livestock, other phenicols, such as florfenicol and thiamphenicol, have been used for the treatment of bacterial infections in domestic cattle in Korea. This study compares the characteristics of chloramphenicol-resistant Enterococcus faecalis isolated from the bulk tank milk of four major dairy companies in Korea. Although the distribution of multidrug resistance patterns showed no significant differences between the four companies, 85 chloramphenicol-resistant Enterococcus faecalis isolates showed a significantly high number of resistances against five or six antimicrobial classes $(37.6 \%$, respectively) $(p<0.05)$. When analyzing the distribution of phenicol resistance genes, 31 (36.5\%) isolates only carried the cat $A$ gene, and two $(6.3 \%)$ isolates from company A only carried the $c f r$ gene. No isolates carried the $c a t B$ or fexA genes. Regarding the distribution of other resistance genes, both the tet $L$ and tetM $(45.9 \%)$, $\operatorname{ermB}(82.4 \%)$, and both $a a c\left(6^{\prime \prime}\right)$-Ie-aph (2") $-\mathrm{la}$ and $\operatorname{ant}\left(6^{\prime}\right)$-Ia genes (30.6\%) showed a high prevalence, and the optrA and poxt $A$ genes were observed separately, each in only two (2.4\%) isolates. Our results confirm that the dissemination of chloramphenicol-resistant Enterococcus faecalis and some antimicrobial resistance genes show significant differences between dairy companies. Therefore, our results support that each dairy company should undertake effective surveillance programs to better understand and minimize the emergence of resistance on a multidisciplinary level.
\end{abstract}

Keywords: Enterococcus faecalis; chloramphenicol resistance; milk; multidrug resistance

\section{Introduction}

Chloramphenicol, a broad-spectrum antimicrobial in human and veterinary medicine in use since the 1950s [1], inhibits translation in bacteria, by inhibiting peptidyl transferase activity, which is mediated by binding to several proteins in the $50 \mathrm{~S}$ ribosomal subunit [2]. However, since chloramphenicol has been shown to cause serious bone marrow suppression and fetal aplastic anemia [1,3], its use in humans and animals has been subsequently limited. It is currently banned from use in food-producing animals in many countries and regions, including the European Union [1], China [4], the United States [5], and Korea [6].

Enterococci are known as a genus of gut-equivalent microorganisms commonly found in animals and humans, but considered to be environmental mastitis-causing pathogens that can enter into milk and milk products via unhygienic food production and handling conditions [7-9]. Moreover, enterococci have been recognized as notoriously opportunistic pathogens that frequently acquire antimicrobial resistance determinants and potential virulence factors $[10,11]$. Resistance to chloramphenicol is mainly caused by the production of inactivating chloramphenicol acetyltransferase (CAT) [1], the genes of which are widely disseminated on plasmids and capable of contributing to multidrug resistance (MDR) 
by conjugative transfer $[12,13]$. Therefore, the occurrence of chloramphenicol-resistant Enterococcus faecalis related MDR from dairy products and farms is often reported [14-18]. This study compares the phenotypic and genotypic characteristics of chloramphenicolresistant $E$. faecalis isolated from the bulk tank milk of four major dairy companies in Korea to provide an insight into the potential emerging problems of Enterococcus spp. in milk.

\section{Materials and Methods}

\subsection{Bacterial Isolation}

A total of 1584 batches of bulk tank milk were aseptically collected from 396 farms affiliated with four dairy companies in Korea in the summer and winter seasons. The isolation and identification of Enterococcus spp. was performed following standard microbiological protocols published by the Ministry of Food and Drug Safety (Korea) (2019) [19]. Briefly, a one $\mathrm{mL}$ milk sample was cultured in nine $\mathrm{mL}$ of buffered peptone water (BPW; BD Biosciences, San Jose, CA, USA). Pre-enriched BPW was then mixed with Enterococcosel broth (BD Biosciences, San Jose, CA, USA) at a 1:10 ratio. After incubation at $37^{\circ} \mathrm{C}$ for 18-24 h, each medium was streaked onto Enterococcosel agar (BD Biosciences, San Jose, CA, USA). Confirmation of E. faecalis was performed via polymerase chain reaction (PCR), with the primer specifically targeted to the $d d l 1$ gene, as described previously [20]. As a result, a total of $301 \mathrm{E}$. faecalis isolates were tested in this study.

\subsection{Antimicrobial Susceptibility Testing}

Antimicrobial susceptibility analysis was performed by broth microdilution according to the Clinical and Laboratory Standards Institute guidelines (2018) [21], using the commercially available Sensititre ${ }^{\circledR}$ panel KRVP2F (TREK Diagnostic Systems, West Sussex, UK), in accordance with the manufacturer's instructions. The antimicrobial classes tested were aminoglycosides (gentamicin, kanamycin, and streptomycin), glycopeptides (vancomycin), ionophores (salinomycin), lipopeptides (daptomycin), macrolides (erythromycin, and tylosin tartrate), oxazolidinones (linezolid), penicillins (ampicillin), phenicols (chloramphenicol and florfenicol), quinolones (ciprofloxacin), and tetracyclines (tetracycline and tigecycline). E. faecalis ATCC 29212 was used as a quality control. If isolates from the same farm showed the same antimicrobial susceptibility pattern, only one isolate was randomly selected. MDR was defined as acquired non-susceptibility to at least one agent in three or more antimicrobial classes [22].

\subsection{Detection of Antimicrobial Resistance and Virulence Genes}

DNA extraction was prepared by boiling, as described previously [23]. The presence of genes conferring resistance to phenicol ( $c f r, \operatorname{cat} A, \operatorname{cat} B$, and $f e x A)$, tetracycline (tet $L$, tet $M$, and tet $O$ ), macrolide (erm A, ermB, and mef), oxazolidinone (optrA and poxt $A$ ), and aminoglycoside (aac(6')-Ie-aph(2")-Ia, aph (2")-Ib, aph (2")-Ic, aph (2")-Id, ant(3")-Ia, and ant (6')-Ia) was investigated by PCR as described previously [24-32]. Genes encoding virulence factors, such as collagen-binding cell wall protein (ace), endocarditis antigen (efa $A)$, aggregation substance (asa1), cytolysin (cylA), Enterococcal surface protein (esp), gelatinase (gelE), and pheromone cAD1 precursor lipoprotein (cad1) were also detected using PCR, as described previously $[33,34]$.

\subsection{Statistical Analysis}

The SPSS 25 statistical package (IBM corp., Armonk, NY, USA) was used for performing statistical analyses. Pearson's chi-squared test and Fisher's exact test with Bonferroni correction were conducted to analyze the differences between the dairy companies, as previously reported [35]. Differences were considered significant at $p<0.05$. 


\section{Results}

\subsection{Prevalence of Chloramphenicol-Resistant E. faecalis}

Among the 301 E. faecalis isolates, 85 (28.2\%) chloramphenicol-resistant E. faecalis isolates were found among the four dairy companies (Table 1). Although company D showed the highest prevalence of E. faecalis, the prevalence of chloramphenicol-resistant E. faecalis was significantly higher in isolates from company A $(61.5 \%)$ than company D $(12.9 \%)(p<0.05)$.

Table 1. Distribution of chloramphenicol-resistant Enterococcus faecalis from bulk tank milk in dairy companies.

\begin{tabular}{cccc}
\hline \multirow{2}{*}{$\begin{array}{c}\text { Dairy } \\
\text { Company }\end{array}$} & No. of Farms $\mathbf{1}^{-}$ & \multicolumn{2}{c}{ No. of Isolates } \\
\cline { 3 - 4 } & 106 & $\begin{array}{c}\text { Enterococcus } \\
\text { faecalis }\end{array}$ & $\begin{array}{c}\text { Chloramphenicol } \\
\text { Resistance (\%) }\end{array}$ \\
\hline A & 47 & 52 & $32(61.5)_{\mathrm{a}}$ \\
$\mathrm{B}$ & 120 & 39 & $16(41.0)_{\mathrm{a}, \mathrm{b}}$ \\
C & 123 & 86 & $21(24.4)_{\mathrm{b}, \mathrm{c}}$ \\
D & 396 & 124 & $16(12.9)_{\mathrm{c}}$ \\
Total & 301 & $85(28.2)$ \\
\hline
\end{tabular}

${ }^{1}$ Bulk tank milk samples were collected each time in the summer and winter seasons by farms. Values in the same column with different subscripts $\left(_{\mathrm{a}-\mathrm{c}}\right)$ differ $(p<0.05)$ for the isolated ratio between the dairy companies.

\subsection{Distribution of Antimicrobial Resistance Patterns}

A total of 85 chloramphenicol-resistant $E$. faecalis isolates showed resistance against two to seven antimicrobial classes (Table 2). Although the distribution of antimicrobial patterns showed no significant differences between the four dairy companies, chloramphenicolresistant $E$. faecalis isolates demonstrated highly significant resistance against five or six antimicrobial classes $(37.6 \%$, respectively) $(p<0.05)$. In addition, all chloramphenicolresistant $E$. faecalis isolates showed the highest resistance to tetracyclines $(96.5 \%)$, followed by aminoglycosides $(92.9 \%)$, macrolides $(85.9 \%)$, lipopeptides $(51.8 \%)$, quinolones $(47.1 \%)$, ionophores $(38.8 \%)$, and oxazolidinones $(9.4 \%)$. All isolates were susceptible to vancomycin (glycopeptides) and ampicillin (penicillins).

Table 2. Antimicrobial resistance patterns of 85 chloramphenicol-resistant Enterococcus faecalis from bulk tank milk in dairy companies.

\begin{tabular}{ccccccc}
\hline \multirow{2}{*}{$\begin{array}{c}\text { No. of } \\
\text { Antimicrobial } \\
\text { Resistance }\end{array}$} & $\begin{array}{c}\text { Resistance } \\
\text { Pattern }\end{array}$ & $\mathbf{A}$ & $\mathbf{B}$ & $\mathbf{C}$ & $\mathbf{D}$ & Total \\
\cline { 3 - 6 } & & $\boldsymbol{n}=\mathbf{3 2}$ & $\boldsymbol{n}=\mathbf{1 6}$ & $\boldsymbol{n}=\mathbf{2 1}$ & $\boldsymbol{n}=\mathbf{1 6}$ & $\boldsymbol{n}=\mathbf{8 5}$ \\
\hline 2 & P-T & $1(3.1)$ & $0(0.0)$ & $0(0.0)$ & $0(0.0)$ & $1(1.2)$ \\
& M-P & $0(0.0)$ & $1(6.3)$ & $0(0.0)$ & $0(0.0)$ & $1(1.2)$ \\
& Total & $1(3.1)$ & $1(6.3)$ & $0(0.0)$ & $0(0.0)$ & $2(2.4)_{\mathrm{c}}$ \\
& A-M-P-T & $3(9.4)$ & $0(0.0)$ & $2(9.5)$ & $1(6.3)$ & $6(7.1)$ \\
& M-P-Q-T & $2(6.3)$ & $0(0.0)$ & $0(0.0)$ & $0(0.0)$ & $2(2.4)$ \\
& A-P-Q-T & $1(3.1)$ & $1(6.3)$ & $0(0.0)$ & $1(6.3)$ & $3(3.5)$ \\
& A-O-P-T & $0(0.0)$ & $1(6.3)$ & $0(0.0)$ & $0(0.0)$ & $1(1.2)$ \\
& A-L-P-T & $0(0.0)$ & $1(6.3)$ & $0(0.0)$ & $0(0.0)$ & $1(1.2)$ \\
& I-L-P-T & $0(0.0)$ & $0(0.0)$ & $1(4.8)$ & $0(0.0)$ & $1(1.2)$ \\
& O-P-Q-T & $0(0.0)$ & $0(0.0)$ & $0(0.0)$ & $1(6.3)$ & $1(1.2)$ \\
& Total & $6(18.8)$ & $3(18.8)$ & $3(14.3)$ & $3(18.8)$ & $15(17.6)_{\mathrm{b}}$ \\
& A-M-P-Q-T & $9(28.1)$ & $2(12.5)$ & $4(19.0)$ & $2(12.5)$ & $17(20.0)$ \\
& A-I-M-P-T & $3(9.4)$ & $0(0.0)$ & $2(9.5)$ & $0(0.0)$ & $5(5.95)$ \\
& A-L-M-P-T & $1(3.1)$ & $2(12.5)$ & $0(0.0)$ & $1(6.3)$ & $4(4.7)$ \\
\hline
\end{tabular}


Table 2. Cont.

\begin{tabular}{|c|c|c|c|c|c|c|}
\hline \multirow{2}{*}{$\begin{array}{c}\text { No. of } \\
\text { Antimicrobial } \\
\text { Resistance }\end{array}$} & \multirow[b]{2}{*}{$\begin{array}{c}\text { Resistance } \\
\text { Pattern }^{1}\end{array}$} & \multicolumn{5}{|c|}{ No. (\%) of Isolates } \\
\hline & & $\begin{array}{c}\text { A } \\
n=32\end{array}$ & $\begin{array}{c}\text { В } \\
n=16\end{array}$ & $\begin{array}{c}C \\
n=21\end{array}$ & $\begin{array}{c}\mathrm{D} \\
n=16\end{array}$ & $\begin{array}{c}\text { Total } \\
n=85\end{array}$ \\
\hline & A-I-L-M-P & $0(0.0)$ & $2(12.5)$ & $0(0.0)$ & $0(0.0)$ & $2(2.4)$ \\
\hline & A-O-P-Q-T & $0(0.0)$ & $0(0.0)$ & $0(0.0)$ & $3(18.8)$ & $3(3.5)$ \\
\hline & A-L-P-Q-T & $0(0.0)$ & $0(0.0)$ & $0(0.0)$ & $1(6.3)$ & $1(1.2)$ \\
\hline & Total & $13(40.6)$ & $6(37.5)$ & $6(28.6)$ & $7(43.8)$ & $32(37.6)_{a}$ \\
\hline \multirow[t]{4}{*}{6} & A-I-L-M-P-T & 7 (21.9) & $4(25.0)$ & $7(33.3)$ & $4(25.0)$ & $22(25.9)$ \\
\hline & A-L-M-P-Q-T & $4(12.5)$ & $1(6.3)$ & $3(14.3)$ & $1(6.3)$ & $9(10.6)$ \\
\hline & A-M-O-P-Q-T & $0(0.0)$ & $0(0.0)$ & $0(0.0)$ & $1(6.3)$ & $1(1.2)$ \\
\hline & Total & $11(34.4)$ & 5 (31.3) & $10(47.6)$ & $6(31.3)$ & $32(37.6)_{a}$ \\
\hline \multirow[t]{4}{*}{7} & A-I-L-M-P-Q-T & $1(3.1)$ & $0(0.0)$ & $1(4.8)$ & $0(0.0)$ & $2(2.4)$ \\
\hline & A-I-L-M-O-P-T & $0(0.0)$ & $1(6.3)$ & $0(0.0)$ & $0(0.0)$ & $1(1.2)$ \\
\hline & A-L-M-O-P-Q-T & $0(0.0)$ & $0(0.0)$ & $1(4.8)$ & $0(0.0)$ & $1(1.2)$ \\
\hline & Total & $1(3.1)$ & $1(6.3)$ & $2(9.5)$ & $0(0.0)$ & $4(4.7)_{b, c}$ \\
\hline
\end{tabular}

\subsection{Distribution of Antimicrobial Resistance Genes}

The distribution of resistance genes in 85 chloramphenicol-resistant E. faecalis isolates is shown in Table 3. In the distribution of phenicol resistance genes, although $52(61.1 \%)$ isolates expressed no resistance genes, 31 (36.5\%) isolates carried only the cat $A$ gene without a significant difference between dairy companies. Two (6.3\%) isolates from company A only carried the $c f r$ gene, and no isolates carried both the cat $B$ and $f e x A$ genes. In the tetracycline resistance genes, the distribution of the tet $M$ gene alone (43.5\%), and both tet $L$ and tet $M$ genes $(45.9 \%)$ was common but showed a significant difference between dairy companies $(p<0.05)$. In the macrolide resistance genes, the prevalence of the erm $B$ gene $(82.4 \%)$ was the highest, and in the oxazolidinone resistance genes, four $(4.7 \%)$ isolates only carried the optrA or poxt $A$ genes. In the distribution of aminoglycoside resistance genes, the ant $\left(6^{\prime}\right)$-Ia gene alone (25.9\%) and both the aac (6")-Ie-aph(2")-la and ant $\left(6^{\prime}\right)$-Ia genes (30.6\%) were common, without a significant difference between dairy companies.

Table 3. Antimicrobial resistance genes in 85 chloramphenicol-resistant Enterococcus faecalis from bulk tank milk in dairy companies.

\begin{tabular}{cccccc}
\hline \multirow{2}{*}{$\begin{array}{c}\text { Antimicrobial } \\
\text { Resistance Gene }\end{array}$} & $\mathbf{A}$ & $\mathbf{B}$ & $\mathbf{C}$ & $\mathbf{D}$ & Total \\
\cline { 2 - 6 } & $\boldsymbol{n}=\mathbf{3 2}$ & $\boldsymbol{n = 1 6}$ & $\boldsymbol{n}=\mathbf{2 1}$ & $\boldsymbol{n}=\mathbf{1 6}$ & $\boldsymbol{n}=\mathbf{8 5}$ \\
\hline Phenicol & & & & \\
cfr & $2(6.3)$ & $0(0.0)$ & $0(0.0)$ & $0(0.0)$ & $2(2.4)$ \\
cat $A$ & $14(43.7)$ & $4(25.0)$ & $8(38.1)$ & $5(31.3)$ & $31(36.5)$ \\
cat $B$ & $0(0.0)$ & $0(0.0)$ & $0(0.0)$ & $0(0.0)$ & $0(0.0)$ \\
fexA & $0(0.0)$ & $0(0.0)$ & $0(0.0)$ & $0(0.0)$ & $0(0.0)$ \\
None & $16(50.0)$ & $12(75.0)$ & $13(61.9)$ & $11(68.7)$ & $52(61.1)$ \\
Tetracycline & & & & \\
tet $L$ & $0(0.0)$ & $1(6.3)$ & $2(9.5)$ & $1(6.3)$ & $4(4.7)$ \\
tet $M$ & $19(59.3) \mathrm{a}$ & $0(0.0)_{\mathrm{b}}$ & $12(57.1) \mathrm{a}$ & $6(37.5) \mathrm{a}$ & $37(43.5)$ \\
tet $O$ & $0(0.0)$ & $0(0.0)$ & $0(0.0)$ & $0(0.0)$ & $0(0.0)$ \\
tet $L+$ tet $M$ & $11(34.4)_{\mathrm{b}}$ & $12(75.0) \mathrm{a}$ & $7(33.3) \mathrm{a}, \mathrm{b}$ & $9(56.2)_{\mathrm{a}, \mathrm{b}}$ & $39(45.9)$ \\
\hline
\end{tabular}


Table 3. Cont.

\begin{tabular}{|c|c|c|c|c|c|}
\hline \multirow[b]{2}{*}{$\begin{array}{c}\text { Antimicrobial } \\
\text { Resistance Gene }\end{array}$} & \multicolumn{5}{|c|}{ No. (\%) of Isolates } \\
\hline & $\begin{array}{c}\mathrm{A} \\
n=32\end{array}$ & $\begin{array}{c}\text { B } \\
n=16\end{array}$ & $\begin{array}{c}C \\
n=21\end{array}$ & $\begin{array}{c}\mathrm{D} \\
n=16\end{array}$ & $\begin{array}{c}\text { Total } \\
n=85\end{array}$ \\
\hline None & $2(6.3)$ & $3(18.7)$ & $0(0.0)$ & $0(0.0)$ & $5(5.9)$ \\
\hline \multicolumn{6}{|l|}{ Macrolide } \\
\hline ermA & $0(0.0)$ & $0(0.0)$ & $0(0.0)$ & $0(0.0)$ & $0(0.0)$ \\
\hline $\mathrm{ermB}$ & $29(90.6) \mathrm{a}$ & $12(75.0)_{\mathrm{a}, \mathrm{b}}$ & $20(95.2)_{a}$ & $9(56.3)_{b}$ & $70(82.4)$ \\
\hline mef & $0(0.0)$ & $0(0.0)$ & $0(0.0)$ & $0(0.0)$ & $0(0.0)$ \\
\hline erm $A+\operatorname{erm} B$ & $0(0.0)$ & $1(6.3)$ & $0(0.0)$ & $0(0.0)$ & $1(1.2)$ \\
\hline None & $3(9.4)_{b}$ & $3(18.7)_{a, b}$ & $1(4.8)_{b}$ & $7(43.7)_{a}$ & $14(16.4)$ \\
\hline \multicolumn{6}{|l|}{ Oxazolidinone } \\
\hline optrA & $0(0.0)$ & $1(6.3)$ & $0(0.0)$ & $1(6.3)$ & $2(2.4)$ \\
\hline $\operatorname{poxt} A$ & $0(0.0)$ & $0(0.0)$ & $1(4.8)$ & $1(6.3)$ & $2(2.4)$ \\
\hline None & $32(100.0)$ & $15(93.7)$ & $20(95.2)$ & $14(87.4)$ & $81(95.2)$ \\
\hline \multicolumn{6}{|l|}{ Aminoglycoside } \\
\hline $\operatorname{aac}\left(6^{\prime \prime}\right)-I e-a p h\left(2^{\prime \prime}\right)-l a$ & $2(6.25)$ & $0(0.0)$ & $0(0.0)$ & $0(0.0)$ & $2(2.4)$ \\
\hline $\operatorname{aph}\left(2^{\prime \prime}\right)-I b$ & $0(0.0)$ & $0(0.0)$ & $0(0.0)$ & $0(0.0)$ & $0(0.0)$ \\
\hline $\operatorname{aph}\left(2^{\prime \prime}\right)-I c$ & $0(0.0)$ & $0(0.0)$ & $0(0.0)$ & $0(0.0)$ & $0(0.0)$ \\
\hline $\operatorname{aph}\left(2^{\prime \prime}\right)-I d$ & $0(0.0)$ & $0(0.0)$ & $0(0.0)$ & $1(6.3)$ & $1(1.2)$ \\
\hline $\operatorname{ant}\left(3^{\prime \prime}\right)-I a$ & $0(0.0)$ & $0(0.0)$ & $0(0.0)$ & $0(0.0)$ & $0(0.0)$ \\
\hline $\operatorname{ant}\left(6^{\prime}\right)-I a$ & $5(15.6)$ & $6(37.5)$ & $5(23.8)$ & $6(37.5)$ & $22(25.9)$ \\
\hline $\begin{array}{c}a a c\left(6^{\prime \prime}\right)-I e-a p h\left(2^{\prime \prime}\right)-l a+ \\
\operatorname{ant}\left(6^{\prime}\right)-I a\end{array}$ & $10(31.3)$ & $5(31.3)$ & $9(42.9)$ & $2(12.5)$ & $26(30.6)$ \\
\hline $\operatorname{aph}\left(2^{\prime \prime}\right)-I c+\operatorname{ant}\left(6^{\prime}\right)-I a$ & $1(3.1)$ & $0(0.0)$ & $1(4.8)$ & $0(0.0)$ & $2(2.4)$ \\
\hline $\operatorname{aph}\left(2^{\prime \prime}\right)-I d+\operatorname{ant}\left(6^{\prime}\right)-I a$ & $1(3.1)$ & $3(18.8)$ & $2(9.5)$ & $3(18.8)$ & $9(10.6)$ \\
\hline $\begin{array}{c}\operatorname{aph}\left(2^{\prime \prime}\right)-I c+\operatorname{aph}\left(2^{\prime \prime}\right)-I d \\
+\operatorname{ant}\left(6^{\prime}\right)-I a\end{array}$ & $0(0.0)$ & $0(0.0)$ & $1(4.8)$ & $0(0.0)$ & $1(1.2)$ \\
\hline None & $13(40.6)$ & $2(12.4)$ & $3(14.2)$ & $4(25.0)$ & $22(25.8)$ \\
\hline
\end{tabular}

$\mathrm{a}, \mathrm{b}$ Values in the same row with different subscripts differ $(p<0.05)$ for the isolated ratios between the dairy companies.

\subsection{Distribution of Virulence Genes}

The distribution of virulence genes in 85 chloramphenicol-resistant $E$. faecalis isolates is shown in Table 4. Although this distribution showed no significant difference between dairy companies, the most prevalent gene was ace $(98.8 \%)$, followed by efa $A(97.6 \%)$, cad 1 (97.6\%), gelE (88.2\%), asa1 (62.4\%), esp (12.9\%), and cylA (10.6\%).

Table 4. Virulence genes in 85 chloramphenicol-resistant Enterococcus faecalis from bulk tank milk in dairy companies.

\begin{tabular}{ccccccc}
\hline & \multicolumn{5}{c}{ No. (\%) of Isolates } & \multirow{2}{*}{$\boldsymbol{p}$} \\
\cline { 2 - 6 } Gene & $\mathbf{A}$ & $\mathbf{B}$ & $\mathbf{C}$ & $\mathbf{D}$ & Total & \\
& $\boldsymbol{n}=\mathbf{3 2}$ & $\boldsymbol{n = 1 6}$ & $\boldsymbol{n = 2 1}$ & $\boldsymbol{n = 1 6}$ & $\boldsymbol{n = 8 5}$ & \\
\hline ace & $32(100.0)$ & $16(100.0)$ & $20(95.2)$ & $16(100.0)$ & $84(98.8)$ & 0.624 \\
efaA & $32(100.0)$ & $15(93.8)$ & $20(95.2)$ & $16(100.0)$ & $83(97.6)$ & 0.386 \\
asa1 & $21(65.6)$ & $12(75.0)$ & $13(61.9)$ & $7(43.8)$ & $53(62.4)$ & 0.308 \\
cylA & $4(12.5)$ & $2(12.5)$ & $3(14.3)$ & $0(0.0)$ & $9(10.6)$ & 0.493 \\
esp & $3(9.4)$ & $2(12.5)$ & $2(9.5)$ & $4(25.0)$ & $11(12.9)$ & 0.513 \\
gelE & $29(90.6)$ & $14(87.5)$ & $16(76.2)$ & $16(100.0)$ & $75(88.2)$ & 0.173 \\
cad1 & $32(100.0)$ & $16(100.0)$ & $20(95.2)$ & $15(93.8)$ & $83(97.6)$ & 0.386 \\
\hline
\end{tabular}

\section{Discussion}

The prevalence of chloramphenicol-resistant enterococci in dairy products has been reported in many countries, including Switzerland (45.9\%), Poland (32.91\%), South Africa $(13 \%)$, and Turkey $(10.7 \%)[9,15,18,36]$. In this study, the total prevalence of chloramphenicolresistant $E$. faecalis isolates $(28.2 \%)$ was also shown similar to other countries, but there were 
significant differences in the distribution of chloramphenicol-resistant $E$. faecalis between the four dairy companies studied $(12.9 \%-61.5 \%)$. In Korea, although chloramphenicol is no longer used in cattle, other phenicols, such as florfenicol and thiamphenicol, have been continuously used for the treatment of bacterial infections in domestic cattle [19]. In particular, florfenicol is commonly recommended for the treatment of bacterial pneumonia and associated respiratory infections caused by Haemophilus somnus, Mannheimia (Pasteurella) haemolytica, and Pasteurella multocida in cattle [37]. Florfenicol inhibits protein synthesis by binding to ribosomal subunits of susceptible bacteria and shares antimicrobial binding sites with chloramphenicol [1]. Because antimicrobial usage generally results in antimicrobial resistance [5], the varying usage of florfenicol between the dairy companies studied could be attributed to the differences seen in the distribution of chloramphenicol resistance.

In this study, 83 (97.6\%) chloramphenicol-resistant E. faecalis isolates demonstrated MDR, especially against five or six classes, which showed a significantly higher prevalence. Chloramphenicol resistance mechanisms in bacteria comprise a reduction in membrane permeability, mutations in $23 \mathrm{~S}$ rRNA, and proliferation of CATs [1]. However, another mechanism of chloramphenicol inactivation is performed by efflux pumps, which are regulated by translation attenuation $[1,38]$. Efflux pumps can contribute to the internal environment by removing toxins or antimicrobial agents [10,39]; therefore, the efflux of chloramphenicol could simultaneously confer resistance to this antimicrobial as well as others $[10,39]$.

As previously described, the most frequently encountered mechanism of resistance is enzymatic inactivation by acetylation of chloramphenicol via CATs, encoded by the cat $A$ and $c a t B$ genes, which are widespread among Gram-positive and Gram-negative bacteria $[1,12]$. Although the $c a t B$ gene has been found in Gram-negative bacteria, the cat $A$ gene is commonly found in Gram-positive bacteria [1]. Jamet et al. [16] reported that 16 of $20(80 \%)$ chloramphenicol-resistant $E$. faecalis isolates from French cheese carried the cat $A$ gene. Hummel et al. [14] also reported that all chloramphenicol-resistant $E$. faecalis isolates from milk, whey, and cheese in their study carried the CAT gene. However, only $36.5 \%$ of chloramphenicol-resistant $E$. faecalis carried the cat $A$ gene in this study, indicating that other MDR-related mechanisms, such as efflux pumps, may be involved in chloramphenicol resistance to E. faecalis in Korea.

Moreover, chloramphenicol resistance can result from changing the binding site of chloramphenicol in cells through a mutation in 23S rRNA [1], facilitated by the phenicol resistance gene $c f r$ [40]. The $c f r$ gene is also known as the MDR gene [40]; therefore, several researchers have highlighted increasing concerns with regard to this gene in public health [31,40-42]. In addition, the cfr gene is thought to be linked to the spread of linezolid resistance [41]. Although Elghaieb et al. [43] and Ahmed et al. [44] reported no cfr gene in $E$. faecalis isolates taken from dairy milk, two cfr-positive, chloramphenicol-resistant $E$. faecalis isolates were detected in this study. However, these two isolates showed no resistance to linezolid.

Although the distribution of the cat $A$ gene showed no significant differences between dairy companies, some resistance genes showed a significant difference. The distribution of the tet $M$ gene alone and both tet $L$ and tet $M$ genes, which are related to tetracycline resistance, is common, but showed significant differences between the four companies. Miller et al. [41] reported that the tetL gene encodes efflux pumps, which are plasmid-borne determinants. Mobile resistance genes carried via plasmids can be easily transferred by conjugation, which allows the sharing of genetic information such as antimicrobial and virulence genes [45]. In this study, isolates from company B showed the highest prevalence of both tet $L$ and tet $M$ genes (75.0\%), and as a result dissemination of tetracycline-resistant pathogens and MDR, including chloramphenicol may be expected to increase further in company B.

In the distribution of macrolide resistance genes, prevalence of the ermB gene (82.4\%) was the highest, but also showed significant differences between dairy companies $(p<0.05)$ isolates from company $\mathrm{A}$ and $\mathrm{C}$ showed $90.6 \%$ and $95.2 \% \mathrm{ermB}$ gene prevalence, respec- 
tively, but only $56.3 \%$ of isolates from company D carried the ermB gene. Moreover, resistance against macrolides was also shown to be higher in isolates from company A $(93.8 \%)$ and C (95.2\%) than company D (62.5\%). The mechanisms of macrolide resistance in enterococci are described as two types: (i) inducible resistance associated with methylation of $23 S$ rRNA by a methylation enzyme, and (ii) resistance associated with an efflux pump $[41,46]$. Although the prevalence of erythromycin-resistant $E$. faecalis from dairy products was reported differently between countries including Korea $(85.4 \%)$, France $(70.9 \%)$, Switzerland $(60.1 \%)$, and Poland $(18.5 \%)$, most erythromycin-resistant E. faecalis isolates were positive for the ermB gene $[15,16,47,48]$. The ermB gene, which is considered to be the most widespread macrolide resistance gene among enterococci in livestock and food, induces target modification via the action of methylase, and either conjugative plasmids such as pAM $\beta 1$, pRE25, and pUW1965, or transposons, such as Tn917, Tn1545, Tn5384, and Tn5385, which carry the ermB gene $[14,15]$. This study suggests that there is a need to further investigate the possibility of mobile resistance gene transfer by sequencing plasmids and detecting genes related to transposon families [49,50].

In this study, eight $(9.4 \%)$ chloramphenicol-resistant $E$. faecalis isolates from three dairy companies showed co-resistance to linezolid. Surprisingly, four (4.7\%) isolates also showed co-resistance to florfenicol and harbored the linezolid resistance genes optrA or poxtA. Linezolid is considered to be a last resort treatment for infections caused by MDR gram-positive pathogens, including vancomycin-resistant Enterococcus spp., methicillin-resistant Staphylococcus spp., and Streptococcus pneumoniae [51]. Recently, the ABC-F transporter gene, poxtA, has been the focus of increasing resistance to phenicols and oxazolidinones [32,52,53]. In addition, a novel gene, optrA, confers resistance against linezolid, tedizolid, and phenicols by encoding an ATP-binding cassette transporter [30]. So far, linezolid resistance genes in E. faecalis from milk and dairy products have not been reported in Korea. Therefore, as previously reported, there is a need for continuous surveillance to monitor the emergence of linezolid-resistant $E$. faecalis in dairy products, as a matter of public health [43].

In this study, among the four dairy companies studied, most chloramphenicol-resistant E. faecalis isolates carried virulence genes including ace, asa1, cad1, efa A, and gelE, although no significant difference was demonstrated between the companies. The presence of virulence genes may contribute to the severity of pathogenesis and accelerate the transfer of antimicrobial resistance genes, which is of public health concern [18].

\section{Conclusions}

In a comparative analysis of E. faecalis isolated from four major dairy companies in Korea, the dissemination of chloramphenicol-resistant $E$. faecalis and some antimicrobial resistance genes showed a significant difference between companies, although the prevalence of MDR showed no significant difference. Therefore, our results support that each dairy company should undertake effective surveillance programs to better understand and minimize the emergence of resistance on a multidisciplinary level.

Author Contributions: Conceptualization, S.H.B. and Y.J.L.; methodology, S.H.B., S.Y., Y.B.K., and Y.J.L.; software, S.H.B. and K.K.; validation, S.H.B., S.Y., and Y.J.L.; formal analysis, S.H.B., K.K., and Y.B.K.; investigation, S.H.B.; resources, S.H.B., S.Y., and Y.J.L.; data curation, S.H.B., K.K., and Y.B.K.; writing—original draft preparation, S.H.B.; writing—review and editing, S.H.B. and Y.J.L.; visualization, S.H.B.; supervision, Y.J.L.; project administration, Y.J.L. All authors have read and agreed to the published version of the manuscript.

Funding: This research received no external funding.

Institutional Review Board Statement: Not applicable.

Informed Consent Statement: Not applicable.

Data Availability Statement: In regard to the data presented in this study, we included it in the article.

Conflicts of Interest: The authors declare no conflict of interest. 


\section{References}

1. Schwarz, S.; Kehrenberg, C.; Doublet, B.; Cloeckaert, A. Molecular basis of bacterial resistance to chloramphenicol and florfenicol. FEMS Microbiol. Rev. 2004, 28, 519-542. [CrossRef]

2. Schlünzen, F.; Zarivach, R.; Harms, J.; Bashan, A.; Tocilj, A.; Albrecht, R.; Yonath, A.; Franceschi, F. Structural basis for the interaction of antibiotics with the peptidyl transferase centre in eubacteria. Nature 2001, 413, 814-821. [CrossRef]

3. Sood, S. Chloramphenicol-A potent armament against multi-drug resistant (MDR) gram negative bacilli? J. Clin. Diagn. Res. 2016, 10, DC01-DC03. [CrossRef] [PubMed]

4. Dang, H.; Ren, J.; Song, L.; Sun, S.; An, L. Dominant chloramphenicol-resistant bacteria and resistance genes in coastal marine waters of Jiaozhou Bay, China. World J. Microbiol. Biotechnol. 2008, 24, 209-217. [CrossRef]

5. Marshall, B.M.; Levy, S.B. Food animals and antimicrobials: Impacts on human health. Clin. Microbiol. Rev. 2011, 24, 718-733. [CrossRef]

6. Nam, H.M.; Lim, S.K.; Kang, H.M.; Kim, J.M.; Moon, J.S.; Jang, K.C.; Kim, J.M.; Joo, Y.S.; Jung, S.C. Prevalence and antimicrobial susceptibility of gram-negative bacteria isolated from bovine mastitis between 2003 and 2008 in Korea. J. Dairy Sci. 2009, 92, 2020-2026. [CrossRef] [PubMed]

7. Myllys, V.; Rautala, H. Characterization of Clinical Mastitis in Primiparous Heifers. J. Dairy Sci. 1995, 78, 538-545. [CrossRef]

8. Rysanek, D.; Zouharova, M.; Babak, V. Monitoring major mastitis pathogens at the population level based on examination of bulk tank milk samples. J. Dairy Res. 2009, 76, 117-123. [CrossRef]

9. Różańska, H.; Lewtak-Piłat, A.; Kubajka, M.; Weiner, M. Occurrence of enterococci in mastitic cow's milk and their antimicrobial resistance. J. Vet. Res. 2019, 63, 93-97. [CrossRef] [PubMed]

10. Aakra, Å.; Vebø, H.; Indahl, U.; Snipen, L.; Gjerstad, Ø.; Lunde, M.; Nes, I.F. The Response of Enterococcus faecalis V583 to Chloramphenicol Treatment. Int. J. Microbiol. 2010, 2010, 483048. [CrossRef]

11. Sava, I.G.; Heikens, E.; Huebner, J. Pathogenesis and immunity in enterococcal infections. Clin. Microbiol. Infect. 2010, 16, 533-540. [CrossRef] [PubMed]

12. Murray, I.A.; Shaw, W.V. O-Acetyltransferases for chloramphenicol and other natural products. Antimicrob. Agents Chemother. 1997, 41, 1-6. [CrossRef] [PubMed]

13. Schwarz, F.V.; Perreten, V.; Teuber, M. Sequence of the 50-kb conjugative multiresistance plasmid pRE25 from Enterococcus faecalis RE25. Plasmid 2001, 46, 170-187. [CrossRef] [PubMed]

14. Hummel, A.; Holzapfel, W.H.; Franz, C.M.A.P. Characterisation and transfer of antibiotic resistance genes from enterococci isolated from food. Syst. Appl. Microbiol. 2007, 30, 1-7. [CrossRef]

15. Templer, S.P.; Baumgartner, A. Enterococci from Appenzeller and Schabziger Raw Milk Cheese: Antibiotic Resistance, Virulence Factors, and Persistence of Particular Strains in the Products. J. Food Prot. 2007, 70, 450-455. [CrossRef]

16. Jamet, E.; Akary, E.; Poisson, M.-A.; Chamba, J.-F.; Bertrand, X.; Serror, P. Prevalence and characterization of antibiotic resistant Enterococcus faecalis in French cheeses. Food Microbiol. 2012, 31, 191-198. [CrossRef]

17. Hammad, A.M.; Hassan, H.A.; Shimamoto, T. Prevalence, antibiotic resistance and virulence of Enterococcus spp. in Egyptian fresh raw milk cheese. Food Control 2015, 50, 815-820. [CrossRef]

18. Tatsing Foka, F.E.; Ateba, C.N. Detection of Virulence Genes in Multidrug Resistant Enterococci Isolated from Feedlots Dairy and Beef Cattle: Implications for Human Health and Food Safety. BioMed Res. Int. 2019, 2019, 5921840. [CrossRef] [PubMed]

19. The Ministry of Food and Drug Safety National antimicrobial use and immunity monitoring. Available online: https: / / www.mfds.go.kr/brd/m_231/view.do?seq=33047\&srchFr=\&srchTo=\&srchWord=\&srchTp=\&itm_seq_1=0\&itm_seq_2=0\& multi_itm_seq=0\&company_cd=\&company_nm=\&page=1 (accessed on 7 April 2021).

20. Dutka-Malen, S.; Evers, S.; Courvalin, P. Detection of glycopeptide resistance genotypes and identification to the species level of clinically relevant enterococci by PCR. J. Clin. Microbiol. 1995, 33, 24-27. [CrossRef]

21. Clinical and Laboratory Standards Institute (CLSI). M100: Performance Standards for Antimicrobial Susceptibility Testing, 28th ed.; Clinical and Laboratory Standards Institute: Wayne, PA, USA, 2018; ISBN 156238838X.

22. Magiorakos, A.P.; Srinivasan, A.; Carey, R.B.; Carmeli, Y.; Falagas, M.E.; Giske, C.G.; Harbarth, S.; Hindler, J.F.; Kahlmeter, G.; Olsson-Liljequist, B.; et al. Multidrug-resistant, extensively drug-resistant and pandrug-resistant bacteria: An international expert proposal for interim standard definitions for acquired resistance. Clin. Microbiol. Infect. 2012, 18, 268-281. [CrossRef] [PubMed]

23. Bakshi, C.S.; Shah, D.H.; Verma, R.; Singh, R.K.; Malik, M. Rapid differentiation of Mycobacterium bovis and Mycobacterium tuberculosis based on a 12.7-kb fragment by a single tube multiplex-PCR. Vet. Microbiol. 2005, 109, 211-216. [CrossRef]

24. Clark, N.C.; Olsvik, Ø.; Swenson, J.M.; Spiegel, C.A.; Tenover, F.C. Detection of a Streptomycin/Spectinomycin Adenylyltransferase Gene ( aadA ) in Enterococcus faecalis. Antimicrob. Agents Chemother. 1999, 43, 157-160. [CrossRef]

25. Aarestrup, F.M.; Agerso, Y.; Gerner-Smidt, P.; Madsen, M.; Jensen, L.B. Comparison of antimicrobial resistance phenotypes and resistance genes in Enterococcus faecalis and Enterococcus faecium from humans in the community, broilers, and pigs in Denmark. Diagn. Microbiol. Infect. Dis. 2000, 37, 127-137. [CrossRef]

26. Vakulenko, S.B.; Donabedian, S.M.; Voskresenskiy, A.M.; Zervos, M.J.; Lerner, S.A.; Chow, J.W. Multiplex PCR for Detection of Aminoglycoside Resistance Genes in Enterococci. Antimicrob. Agents Chemother. 2003, 47, 1423-1426. [CrossRef] [PubMed]

27. Kehrenberg, C.; Schwarz, S. Distribution of Florfenicol Resistance Genes fexA and cfr among Chloramphenicol-Resistant Staphylococcus Isolates. Antimicrob. Agents Chemother. 2006, 50, 1156-1163. [CrossRef] [PubMed] 
28. Sepúlveda, M.A.; Bello, H.T.; Domínguez, M.Y.; Mella, S.M.; Zemelman, R.Z.; González, G.R. Identificación molecular de enzimas modificantes de aminoglucósidos en cepas de Enterococcus spp. aisladas en hospitales de la Octava Región de Chile. Rev. Med. Chil. 2007, 135, 566-572. [CrossRef]

29. Di Cesare, A.; Luna, G.M.; Vignaroli, C.; Pasquaroli, S.; Tota, S.; Paroncini, P.; Biavasco, F. Aquaculture Can Promote the Presence and Spread of Antibiotic-Resistant Enterococci in Marine Sediments. PLoS ONE 2013, 8, e62838. [CrossRef] [PubMed]

30. Wang, Y.; Lv, Y.; Cai, J.; Schwarz, S.; Cui, L.; Hu, Z.; Zhang, R.; Li, J.; Zhao, Q.; He, T.; et al. A novel gene, optrA, that confers transferable resistance to oxazolidinones and phenicols and its presence in Enterococcus faecalis and Enterococcus faecium of human and animal origin. J. Antimicrob. Chemother. 2015, 70, 2182-2190. [CrossRef]

31. Osman, K.M.; Badr, J.; Orabi, A.; Elbehiry, A.; Saad, A.; Ibrahim, M.D.S.; Hanafy, M.H. Poultry as a vector for emerging multidrug resistant Enterococcus spp.: First report of vancomycin (van) and the chloramphenicol-florfenicol (cat-fex-cfr) resistance genes from pigeon and duck faeces. Microb. Pathog. 2019, 128, 195-205. [CrossRef]

32. Huang, J.; Wang, M.; Gao, Y.; Chen, L.; Wang, L. Emergence of plasmid-mediated oxazolidinone resistance gene poxtA from CC17 Enterococcus faecium of pig origin. J. Antimicrob. Chemother. 2019, 74, 2524-2530. [CrossRef] [PubMed]

33. Billström, H.; Lund, B.; Sullivan, Å.; Nord, C.E. Virulence and antimicrobial resistance in clinical Enterococcus faecium. Int. J. Antimicrob. Agents 2008, 32, 374-377. [CrossRef]

34. Song, H.; Bae, Y.; Jeon, E.; Kwon, Y.; Joh, S. Multiplex PCR analysis of virulence genes and their influence on antibiotic resistance in Enterococcus spp. isolated from broiler chicken. J. Vet. Sci. 2019, 20, e26. [CrossRef]

35. Yoon, S.; Lee, Y.J. Molecular Characteristics of Enterococcus faecalis and Enterococcus faecium from Bulk Tank Milk in Korea. Animals 2021, 11, 661. [CrossRef] [PubMed]

36. Erbas, G.; Parin, U.; Turkyilmaz, S.; Ucan, N.; Ozturk, M.; Kaya, O. Distribution of Antibiotic Resistance Genes in Enterococcus spp. Isolated from Mastitis Bovine Milk. Acta Vet. Brno 2016, 66, 336-346. [CrossRef]

37. Lobell, R.D.; Varma, K.J.; Johnson, J.C.; Sams, R.A.; Gerken, D.F.; Ashcraft, S.M. Pharmacokinetics of florfenicol following intravenous and intramuscular doses to cattle. J. Vet. Pharmacol. Ther. 1994, 17, 253-258. [CrossRef] [PubMed]

38. Lovett, P.S. Translational attenuation as the regulator of inducible cat genes. J. Bacteriol. 1990, 172, 1-6. [CrossRef] [PubMed]

39. Verma, P.; Tiwari, M.; Tiwari, V. Efflux pumps in multidrug-resistant Acinetobacter baumannii: Current status and challenges in the discovery of efflux pumps inhibitors. Microb. Pathog. 2021, 152, 104766. [CrossRef]

40. Liu, Y.; Wang, Y.; Wu, C.; Shen, Z.; Schwarz, S.; Du, X.-D.; Dai, L.; Zhang, W.; Zhang, Q.; Shen, J. First Report of the Multidrug Resistance Gene cfr in Enterococcus faecalis of Animal Origin. Antimicrob. Agents Chemother. 2012, 56, 1650-1654. [CrossRef] [PubMed]

41. Miller, W.R.; Munita, J.M.; Arias, C.A. Mechanisms of antibiotic resistance in enterococci. Expert Rev. Anti-Infect. Ther. 2014, 12, 1221-1236. [CrossRef] [PubMed]

42. Zhang, Y.; Dong, G.; Li, J.; Chen, L.; Liu, H.; Bi, W.; Lu, H.; Zhou, T. A high incidence and coexistence of multiresistance genes cfr and optrA among linezolid-resistant enterococci isolated from a teaching hospital in Wenzhou, China. Eur. J. Clin. Microbiol. Infect. Dis. 2018, 37, 1441-1448. [CrossRef]

43. Elghaieb, H.; Freitas, A.R.; Abbassi, M.S.; Novais, C.; Zouari, M.; Hassen, A.; Peixe, L. Dispersal of linezolid-resistant enterococci carrying poxtA or optrA in retail meat and food-producing animals from Tunisia. J. Antimicrob. Chemother. 2019, 74, $2865-2869$. [CrossRef]

44. Ahmed, W.; Neubauer, H.; Tomaso, H.; El Hofy, F.I.; Monecke, S.; Abd El-Tawab, A.A.; Hotzel, H. Characterization of Enterococciand ESBL-Producing Escherichia coli Isolated from Milk of Bovides with Mastitis in Egypt. Pathogens 2021, 10, 97. [CrossRef]

45. Choi, J.-M.; Woo, G.-J. Transfer of Tetracycline Resistance Genes with Aggregation Substance in Food-Borne Enterococcus faecalis. Curr. Microbiol. 2015, 70, 476-484. [CrossRef]

46. Alekshun, M.N.; Levy, S.B. Molecular Mechanisms of Antibacterial Multidrug Resistance. Cell 2007, 128, 1037-1050. [CrossRef]

47. Kim, J.; Lee, S.; Choi, S. Copper resistance and its relationship to erythromycin resistance in Enterococcus isolates from bovine milk samples in Korea. J. Microbiol. 2012, 50, 540-543. [CrossRef]

48. Chajęcka-Wierzchowska, W.; Zadernowska, A.; García-Solache, M. Ready-to-eat dairy products as a source of multidrug-resistant Enterococcus strains: Phenotypic and genotypic characteristics. J. Dairy Sci. 2020, 103, 4068-4077. [CrossRef]

49. Tantivitayakul, P.; Lapirattanakul, J.; Vichayanrat, T.; Muadchiengka, T. Antibiotic Resistance Patterns and Related Mobile Genetic Elements of Pneumococci and $\beta$-Hemolytic Streptococci in Thai Healthy Children. Indian J. Microbiol. 2016, 56, 417-425. [CrossRef] [PubMed]

50. Kim, Y.B.; Seo, K.W.; Jeon, H.Y.; Lim, S.K.; Sung, H.W.; Lee, Y.J. Molecular characterization of erythromycin and tetracyclineresistant Enterococcus faecalis isolated from retail chicken meats. Poult. Sci. 2019, 98, 977-983. [CrossRef] [PubMed]

51. Sadowy, E. Linezolid resistance genes and genetic elements enhancing their dissemination in enterococci and streptococci. Plasmid 2018, 99, 89-98. [CrossRef] [PubMed]

52. Hao, W.; Shan, X.; Li, D.; Schwarz, S.; Zhang, S.-M.; Li, X.-S.; Du, X.-D. Analysis of a poxtA- and optrA-co-carrying conjugative multiresistance plasmid from Enterococcus faecalis. J. Antimicrob. Chemother. 2019, 74, 1771-1775. [CrossRef]

53. Na, S.H.; Moon, D.C.; Kim, M.H.; Kang, H.Y.; Kim, S.J.; Choi, J.H.; Mechesso, A.F.; Yoon, S.S.; Lim, S.K. Detection of the phenicol-oxazolidinone resistance gene poxta in enterococcus faecium and enterococcus faecalis from food-producing animals during 2008-2018 in Korea. Microorganisms 2020, 8, 1839. [CrossRef] [PubMed] 